\title{
Systematic Review of The Literature on The Concept of Civil Society in The Quadruple Helix Framework
}

\author{
Paulina González-Martinez ${ }^{1}$,Domingo García-Pérez-De-Lema ${ }^{1}$, Mauricio Castillo-Vergara² Peter Bent Hansen $^{3}$
}

\begin{abstract}
The literature has shown the importance of incorporating civil society into the regional innovation system to favor companies' long-term growth. This research aims to carry out a systematic review on the definition and classification of society in the innovation model based on the contexts that relate to the university, business, and government. The results show that the concept of civil society has been approached in the literature from four perspectives: demand-side, media and culture, independent non-profit, and intermediary organizations. These results may help clarify the concept of civil society, having significant implications for academics and companies, and regional innovation agencies that promote the participation of civil society in their innovation systems.
\end{abstract}

Keywords: quadruple helix, society, citizen, innovation, innovation

Submitted: August 28 $8^{\text {th }}, 2021 /$ Approved: December 14 $4^{\text {th }}, 2021$

\section{Introduction}

Innovation is a very relevant factor that allows companies to obtain a sustainable competitive advantage (Vermeulen, 2004) and has a direct impact on regional economic growth (Malik et al., 2021).). There are different systemic approaches to studying innovation. Among others are the regional innovation systems, the triple and the fourth helix (Geldes \& Heredia, 2016). The triple helix focuses the innovation model on the relationships between firms, universities, and government to explain the development of knowledge-based economies (Etzkowitz and Leydesdorff, 2000), where society's structure is continuously altered transformations originating in techno-sciences (Leydesdorff, 2012). The triple helix innovation process is characterized by academia, government, and industry acting together to create or discover new knowledge, technology, or products and services that can be transmitted to users (Macgregor, Marques-gou, \& Simon-Villar, 2010). The quadruple helix adds another group of actors to the cooperation model (Parveen, Senin, \& Umar, 2015). It arises as a consequence of the fact that the triple helix is not a sufficient condition for innovative long-term growth and that civil society must play an active role in knowledge creation and sustainable growth (Macgregor, Marques-Gou, \& Simon-Villar, 2010). Quadruple helix initiatives have recently materialized in several projects in which civil society organizations are intentionally involved in the organization of innovation systems (Lindberg, Lindgren, \& Packendorff, 2014). The quadruple helix model focuses on the users of innovation and favors the development of innovations that are suitable for the users (civil society) (E. G. Carayannis \& Rakhmatullin, 2014).

The elements that define the fourth helix are: citizens influenced by media and culture, civil society, as well as "art, artistic research, and art-based innovation." The influence of media and culture integrates and combines two forms of 'capital.' From the perspective of culture (e.g., tradition, values, etc.), there is "social capital." While the media optic (e.g., television, internet, newspapers, etc.) also contains 'information capital' (e.g., news, communication, social networks) (E. G. Carayannis et al., 2012). All this represents the prospect of a "democratic dimension" or "democratic context" for knowledge, knowledge production, and innovation (Carayannis \& Campbell, 2017). This quadruple helix concept encourages considering societal and democratic perspectives to support, promote and advance knowledge production (research) and knowledge application (in innovation) (Mavroeidis \& Tarnawska, 2017).

This research aims to conduct a systematic review of the literature on the concept of civil society in the quadruple helix model, based on the contexts that relate to the university, business, and government. This review is carried out in two phases: first, a bibliometric analysis is performed for 2009-2020, based on the Web of Science and Scopus databases; and second, content analysis is performed on the selected papers that address the concept of civil society. In recent years, there has been a growing number of publications that have developed applications of the quadruple helix model in different contexts (Galvao et al., 2019) and incorporate civil society in various forms of collaboration: sustainable green resources, eco-innovation, or smart cities (Galvao et al., 2019). However, the concept of civil society is not clearly defined by the literature (Nordberg, 2015). Defining civil society has become a challenge, as it depends, in many cases, on the analytical purpose of the studies conducted (Aryati, 2017).

\section{Methodology}

In this work, we follow the method suggested by Snyder (2019) and Vallaster et al. (2019). The one that adopts a two-step approach to deepen understanding a phenomenon. The review uses bibliometrics and content analysis. Combining these two methods aims to determine trends in the literature demonstrated by a detailed review of topics and articles (Agostini \& Nosella, 2018). Bibliometrics uses

(1) Universidad Politécnica de Cartagena, España

(2) Universidad Alberto Hurtado, Chile

(3) Universidade Federal do Rio Grande do Sul, Brazil

*Corresponding author: mhcastillo@uahurtado.cl 
activity indicators to measure productivity; quality indicators, citation frequency; and relationship indicators, based on keywords (Martínez et al., 2014). Content analysis allows confirming patterns associated with specific topics (Vallaster et al., 2019).

The study is based on analyzing the concept of civil society in the quadruple helix model. The information of the papers was retrieved from Clarivate and Scopus Web of Science databases, from all categories (Loi et al., 2016). The following search criteria were used: "(Quadruple Helix OR Triple Helix OR Quintuple Helix OR Quadruple Helix Model OR Triple Helix Model OR Quintuple Helix Model OR Quintuple Helix Model)" which can be contained in the title, abstract, or keywords of the articles. The resulting database corresponds to 644 records.

To ensure that each paper is relevant to the concept of civil society, the authors analyzed the abstracts and keywords of the 644 papers. They identified 108 articles that address the concept of civil society from the perspective of the triple, quadruple or quintuple helix. With this selection, a single record is created in a file containing the variables author, language, year of publication, country of authors, keywords, and references cited for each article. The tools used for bibliometric analysis are: the VOSviewer software for constructing bibliometric maps (Waltman \& Van Eck, 2012) and the Bibliometrix software, an open-source program proposed to perform comprehensive comprehensive comprehensive bibliometric analysis (Aria \& Cuccurullo, 2017).

\section{Analysis of Results}

\subsection{Descriptive analysis}

Of the total number of publications, the journals that most deals with this topic are Journal of the Knowledge Economy with 15 articles, R \& D Management with eight publications, Technological Forecasting and Social Change with six articles, Scientometrics with four articles, and Sustainability with 3 . A total of 278 authors have researched the subject, the most important in terms of citations being Etzkowitz $\mathrm{H}$., Carayannis EG., and Leydesdorff L.

A total of 37 countries are represented in terms of authors' affiliation. The most productive are the United Kingdom, Finland, Italy, Korea, and Portugal. Figure 1 shows the number of contributions from the top 20 countries. It is possible to visualize the number of works developed in collaboration with other countries and those with the participation of a single country.

Figure 1. Countries of origin of authors

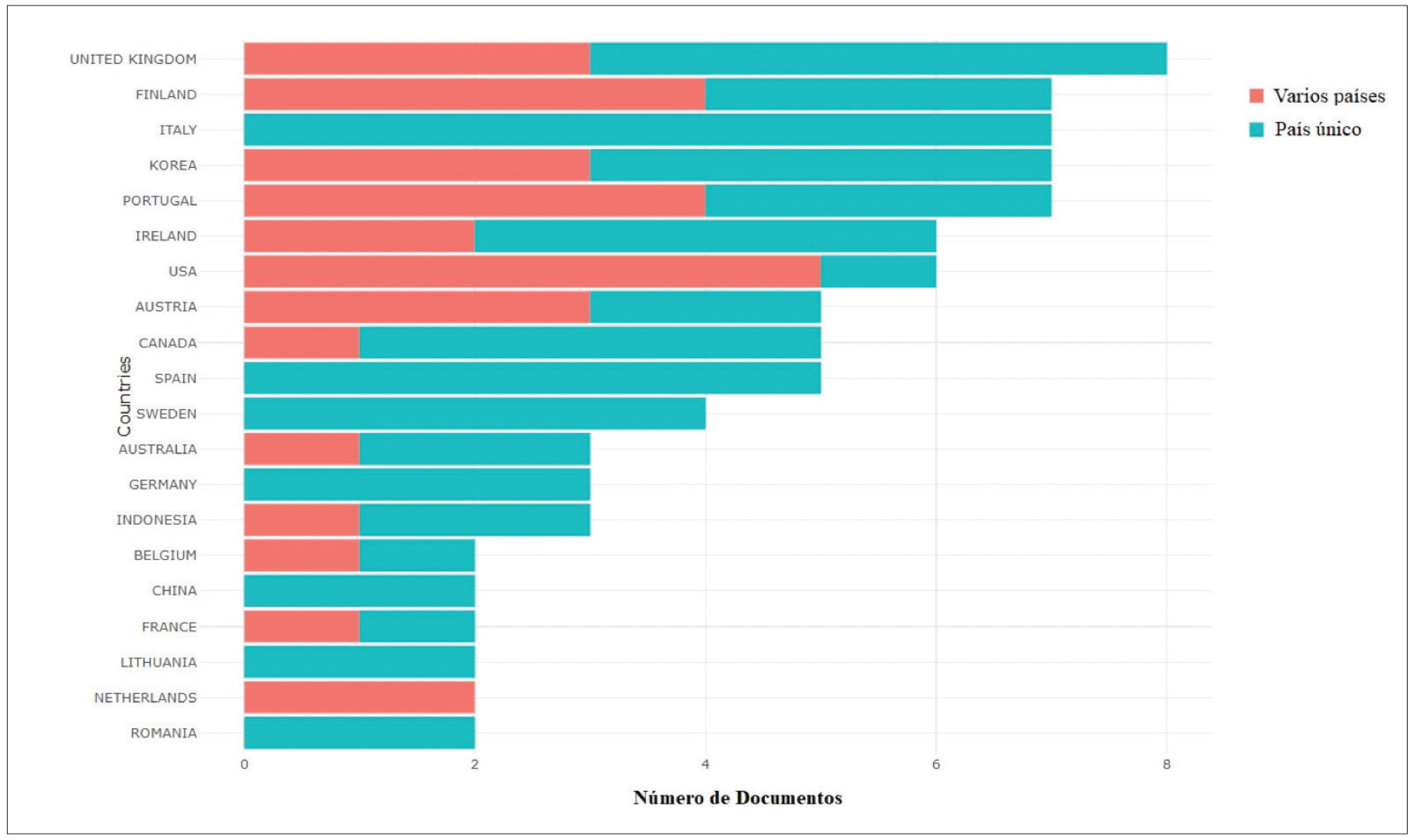


The results also show that the number of authors publishing "n" papers on civil society in the context of the triple, the quadruple, and the quintuple helix is inversely proportional to " $\mathrm{n} 2$ ", fulfilling the probability distribution that describes the productivity of authors, known as Lotka's law (1926). Figure 2 shows this distribution, in which it is possible to identify that 258 authors contribute $93 \%$ of the scientific production.

Figure 2. Lotka's Law

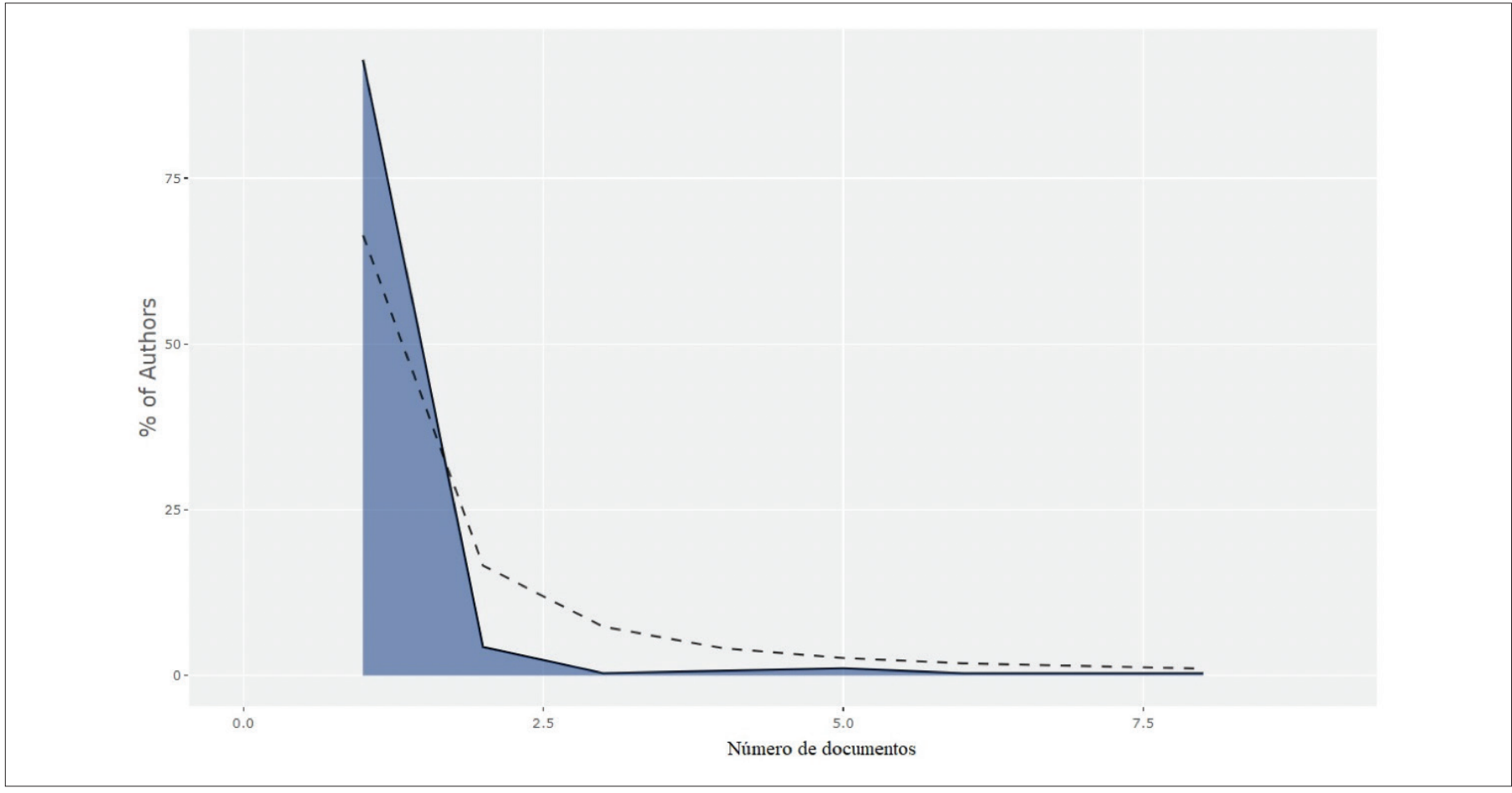

Figure 3 shows the word tree. It corresponds to the representation of each of the concepts. The relative weight of each word is expressed as a function of the total and the number of occurrences. The concepts triple helix, innovation, system, industry, universities, knowledge, and policy stand out.

Figure 3. Keyword cloud
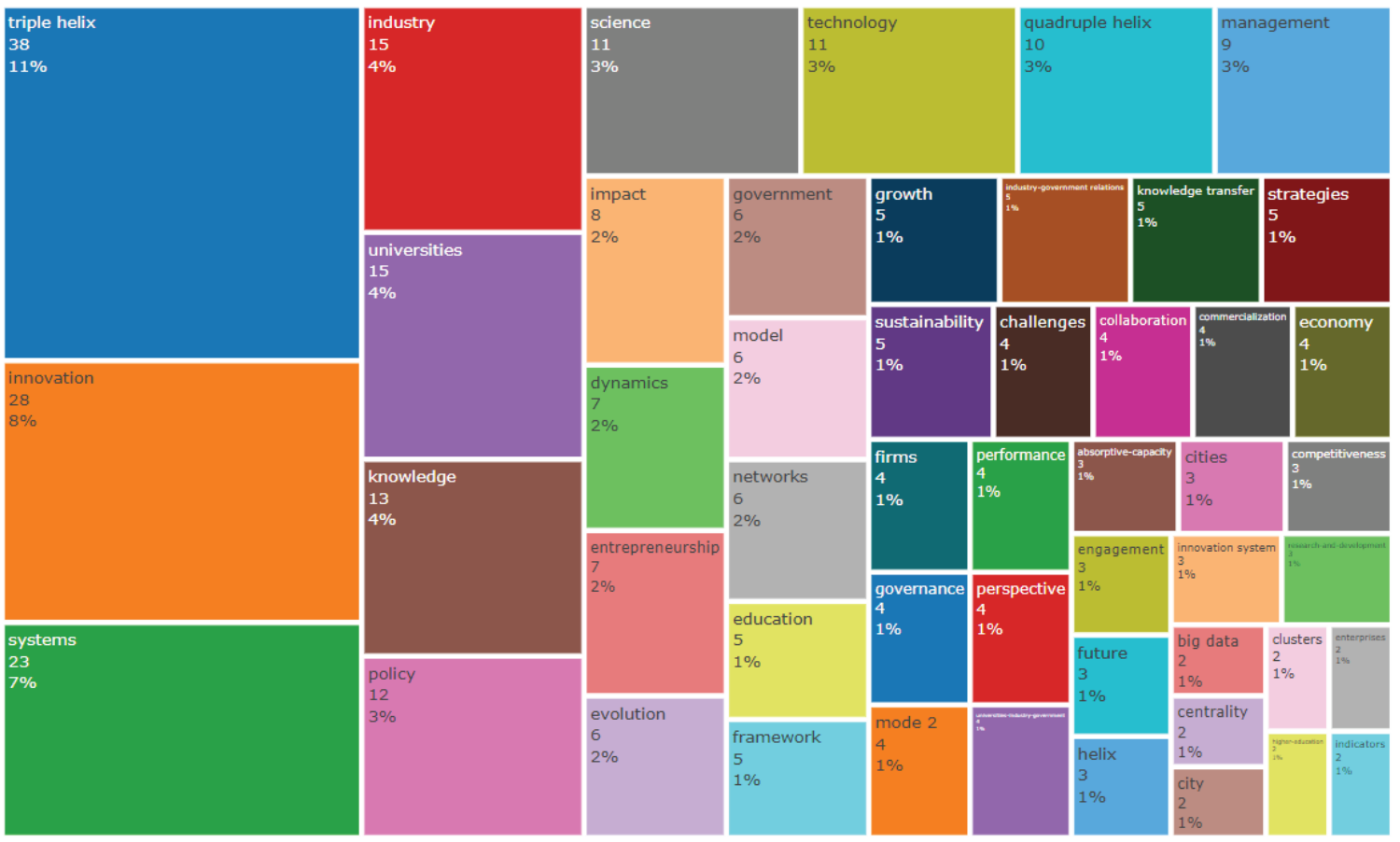

5
$1 \%$

$\%$

ISSN: 0718-2724. (http://jotmi.org) 
The co-occurrence analysis based on the statistics of keywords that appear in the subject of the documents forms a network and clusters called maps. A minimum of 50 occurrences has been used. The size indicates the relevance of an element, and colors are used to group the elements (Mulet-Forteza et al., 2018). There are 5 clusters formed represented in Figure 4.

Figure 4. Co-occurrence map of words

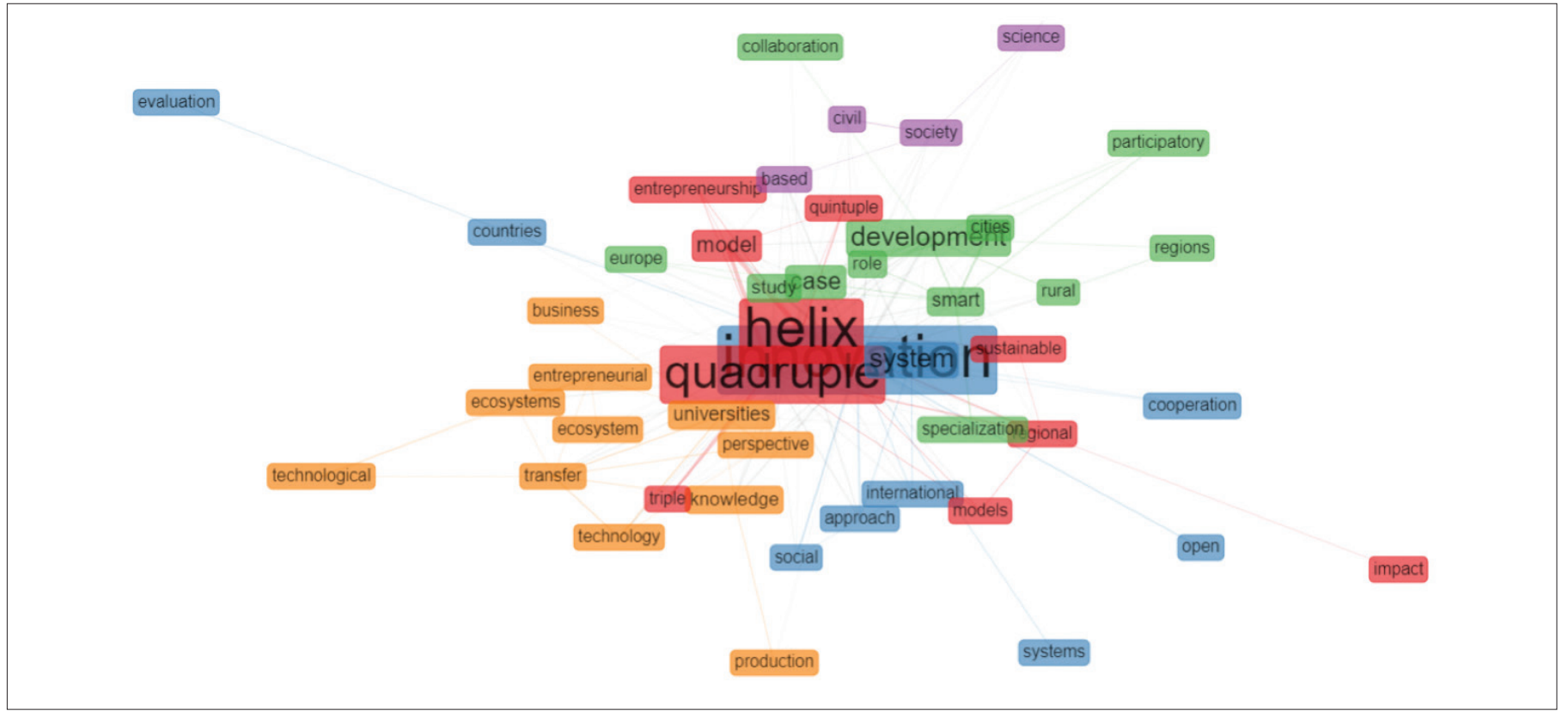

Figure 5 shows the word trends from the title by period; a threshold of at least four occurrences has been used. It is interesting to visualize that the triple helix model remains exclusively in force until 2017, when the concept of partnership, relative to the quadruple helix, makes its appearance. In this framework, the development of innovation emerges as the most important result to be developed. The research raises several studies, models, systems, and cases whose participation of society, cities, and social aspects influence the relationship between governments, companies, and universities.

Figure 5. Word Trend

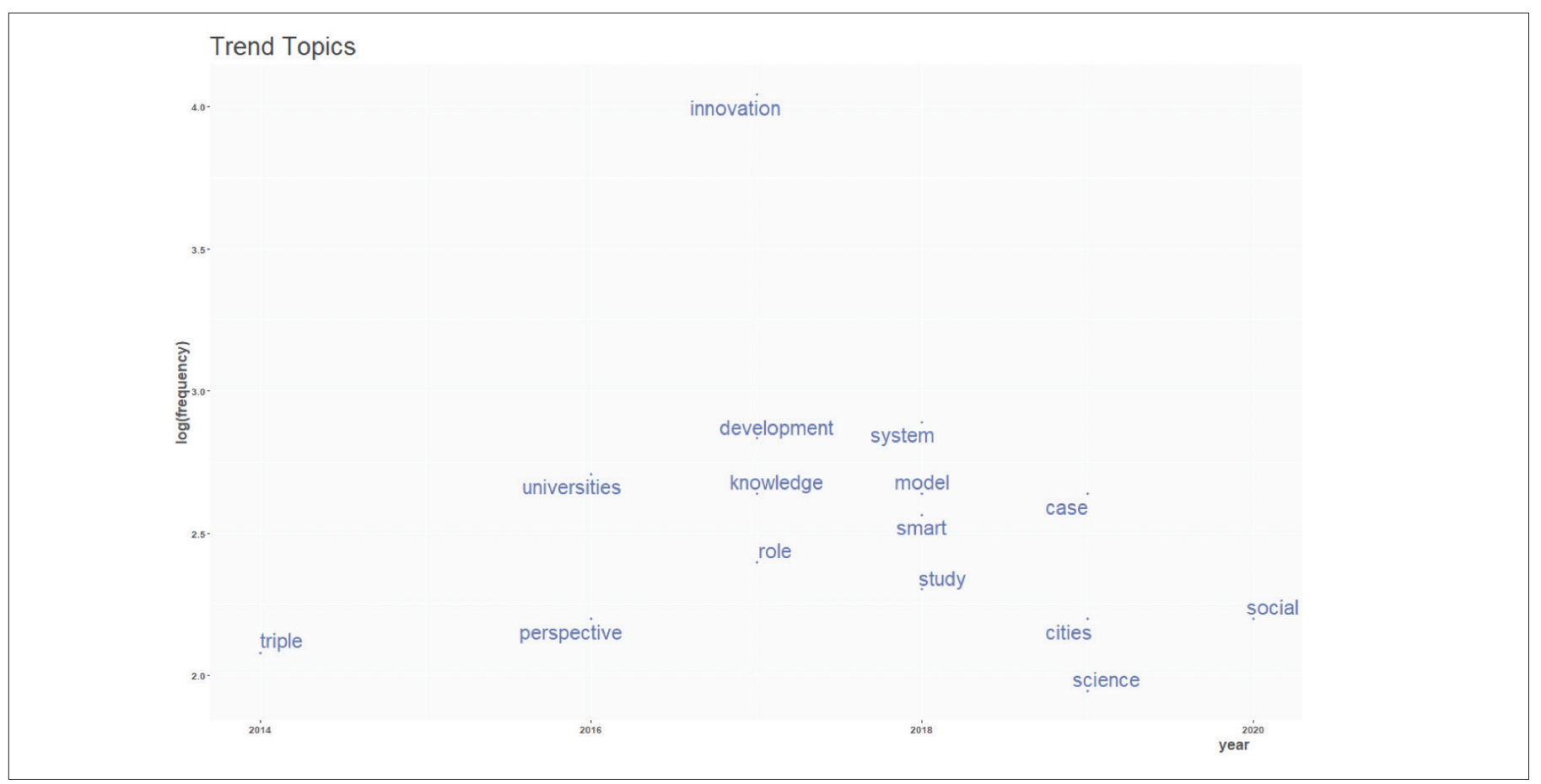


Figure 6 shows the strategic map of the research. It is interesting to note the evolution during the analysis time. This visualization technique shows the clusters detected in a two-dimensional space according to their centrality and density range values. As established by (Callon et al. 1991), centrality measures for a cluster the intensity of its links with other clusters; that is, it measures the degree of interaction of a network with other networks, while density measures the internal strength of the network, characterizing the strength of the network. The links that unite the words that form the group. As expected, one of the most developed concepts is the quadruple helix. Additionally, the concepts of innovation and knowledge mark the axes on which the quadruple helix field has been developed. This situation is related to the impacts expected in the quadruple helix framework, which establishes the innovation model in the relationship between companies, universities, and government to explain the development of knowledge-based economies, focusing on users (Etzkowitz and Leydesdorff, 2000).

Figure 6. Strategy Map

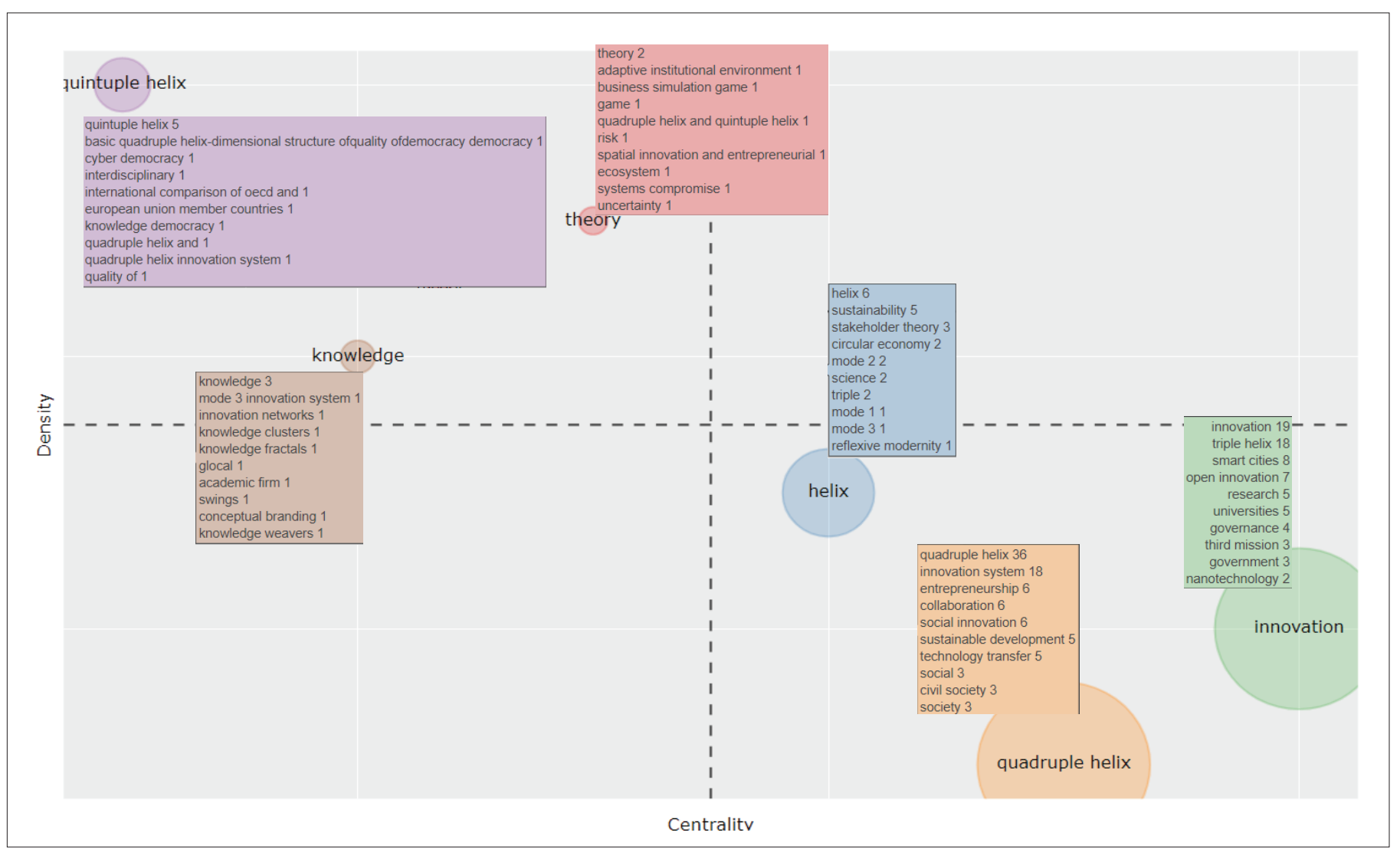

The bibliometric review carried out and presented in the previous sections sustain that the triple helix is neither sufficient nor exclusive to explain the growth of innovation in the long term. It is important to integrate the citizens' perspective, so the quadruple helix adds a helix to the innovation system: civil society. During the last few years, a growing number of publications have discussed the quadruple helix in different contexts, where civil society is integrated with various forms, the most developed being that which considers regional innovation systems and the synergies that these systems generate (Grundel \& Dahlström, 2016; Ivanova, 2019; Porto-Gomez et al., 2019; Ranga, 2018). It is also included for the development of smart cities (Ardito et al., 2019; Grimaldi \& Fernandez, 2017; Mora et al., 2019) and dynamic innovation micro-macros with quadruple helix approaches (Yun \& Liu, 2019) (Paniccia \& Baiocco, 2018) (Cunningham \& O'Reilly, 2018). However, there are antecedents on which there is still some way to go; the existing relationship between the quadruple helix model and civil society evidence one of the relevant challenges when connecting innovation with society. In addition to establishing the participating actors of civil society and the role, they play in participating in the $4 \mathrm{H}$ model.

\subsection{Content Analysis}

In the first instance, it is relevant to dwell on the importance of sustaining the incorporation of this helix in the regional innovation model. Some authors have concluded that the partnership is important because it develops links between scientists, science, and strategies for education (Iqbal et al., 2018). On the other hand, it is indicated that the fourth helix represents the perspective of the dimension of democracy or the context of democracy for knowledge, knowledge production, and innovation (Casaramona et al., 2015). The fourth helix, to different extents, adds the knowledge of human life to the innovation process, together with scientific and technological knowledge (Nordberg, 2015). On the other hand, civil society can become a resource for markets, companies, and business activities and a means 
for companies to adapt to market demands without the risks involved in product development (Grundel \& Dahlström, 2016). Thus, it is understood that, depending on the increasing level of societal involvement in the quadruple helix model, innovation practices can be performed for, with, or by end-users (Del Vecchio et al., 2017). Society and community members are linked to business, technology, services, and science (Mahr, 2017), contributing to the construction of innovation pathways, and promoting the socio-economic growth of the territory (Charalabidis et al., 2019). Additionally, it is possible to extract that the fourth helix is human-centered and focused on democratic knowledge and in favor of arts, artistic research, and artsbased innovation (Hasche et al., 2020).

The definition made by Del Vecchio et al. (2017) points out that from an innovation perspective, the civil society approach: when the innovation practice is performed "for" or "with" users we speak of userdriven or user-centered innovation, i.e., the end-user has a very influential role in the innovation process and actively participates in all its phases, they act as co-designers and co-producers of innovation, playing as important a role in the innovation process as universities and research centers. This first definition differs from innovation "by" users, which is an emblematic case of user-driven innovation.

Consequently, users in the quadruple helix framework can be defined differently depending on the context (Hasche et al., 2020). Ponchek (2016), in his analysis, indicates that:

- $\quad$ From the classical point of view, the fourth pillar is the public, defined more specifically as the public and civil society based on media and culture.

- From the point of view of organizations that favor innovation, the fourth pillar refers to intermediate organizations that act as intermediaries and networks between HT organizations.

- $\quad$ From the point of view of coordinating emerging fields of knowledge, the fourth pillar refers to independent non-profit organizations.

But then the question arises. What kind of organizations, users, citizens, etc., are the ones we should incorporate if we want to evaluate the quadruple helix? The answer considers all those civil society actors outside the family's scope, the state, and the market where people associate to promote the common interest (Aryati, 2017). And can be distinguished from academia, industry, and government in the triple helix metaphor (Yang \& Holgaard, 2012), those that lack the political power and authority of government and academia and the economic power of industry (Borkowska \& Osborne, 2018). Specifically, we can add that civil society actors can be defined as:

\footnotetext{
- $\quad$ Media

- Creative industries

- Cultural activities

- Consumers
}

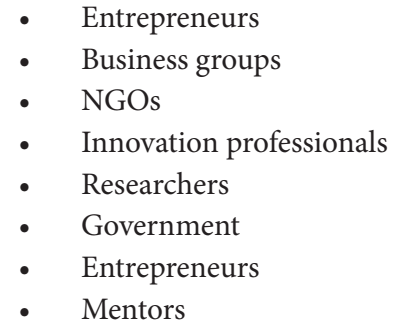

A review of the abstracts of the selected articles was performed to determine which should and should not be included in the systematic analysis. The criteria for this selection were defined using the authors' experience in innovation and society-based studies. Following that, the 108 articles were read and coded for the study's country, keywords, and other factors considered in the descriptive analysis.

In the last instance, the concepts found in the definitions of the different authors were grouped to make an efficient classification of the definitions of civil society possible.

Finally, in the content analysis of the works included in the bibliometric, four perspectives where the studies concentrate the concept of civil society emerged (Table 1 shows the different authors according to the perspective of the concept considered). These are:

1. Society from the demand perspective: users and consumers of innovation (Roman et al., 2020). They actively participate in the innovation process in each of its phases, and, on the other hand, there are those end users, only those who act as "consumers." Yan (2012) showed that civil society plays an important role in lifestyle, consumer behavior, and institutional social participation as a user of goods and services. This quadruple helix model puts the users of innovation at the center and encourages the development of relevant innovations (civil society). Users or citizens are the owners and drivers of innovation processes (Carayannis \& Rakhmatullin, 2014). Civil society is usually the end-user of innovation and strongly influences the generation of knowledge and technologies through its demand function (Mona Roman et al., 2020). Society is usually the end-user of innovation and therefore has a strong influence on the generation of knowledge and technologies through its demand and user function (Carayannis \& Grigoroudis, 2016).

2. Society from the perspective of media and culture. This fourth helix is associated with "media", "creative industries", "culture", "values", "lifestyles", "art", and perhaps also with the notion of “creative class"” (Carayannis \& Campbell 2009).

3. Society from the perspective of independent non-profit organizations. The role of civil society and citizens is considered particularly valuable in strengthening social innovations in the regions (Mona Roman et al., 2020). From a more democratic perspective, the fourth helix can be defined as including citizens, NGOs, trade unions, and others to more growth-oriented perspectives such as consumers and users (Grundel \& Dahlström, 2016). 
4. Society from the perspective of intermediary organizations acting as intermediaries and networks between TH organizations. The intermediary organizations. In the context of university-industry research centers, these organizations can be inter- nal to universities (i.e., technology transfer offices), external (non-profit and/or government-sponsored collective research centers), or between the two (incubator companies or science parks). (Wright et al. 2008). (Van Horne \& Dutot, 2017).

Table 1. Perspectives on the concept of civil society

\begin{tabular}{|c|c|}
\hline Concept of civil society & Authors \\
\hline Demand perspectives & $\begin{array}{l}\text { (Johnson, 2008); (Carayannis \& Campbell, 2009); (Etzkowitz \& Viale, 2010); (Arnkil et al., 2010); (Afon- } \\
\text { so et al., 2012); (E. G. Carayannis et al., 2012); (Schoonmaker \& Carayannis, 2013); (Björk, 2014); (Ca- } \\
\text { rayannis \& Rakhmatullin, 2014); (Carayannis \& Grigoroudis, 2016); (McAdam et al., 2016); (Miller et } \\
\text { al., 2016); (Del Vecchio et al., 2017); (Mahr, 2017); (Carayannis et al., 2018); (Charalabidis et al., 2019); } \\
\text { (Schütz et al., 2019); (Hasche et al., 2020); (Kang \& Jiang, 2020); (Roman et al., 2020); (Terstriep et al., } \\
\text { 2020) }\end{array}$ \\
\hline $\begin{array}{l}\text { The perspective of independent } \\
\text { not-for-profit organizations }\end{array}$ & $\begin{array}{l}\text { (Lindberg et al., 2012); (Klenk \& Hickey, 2013); (Lindberg et al., 2014); (Nordberg, 2015); (Dameri et } \\
\text { al., 2016); (Kolehmainen et al., 2016); (Aryati, 2017); (Yoon et al., 2017); (Charalabidis et al., 2019); } \\
\text { (García-Terán \& Skoglund, 2019); (Gedminaitè-Raudoné et al., 2019); (Mora et al., 2019); (Dhewanto et } \\
\text { al., 2020); (Vilkè et al., 2020) }\end{array}$ \\
\hline $\begin{array}{l}\text { The perspective of intermediate or- } \\
\text { ganizations }\end{array}$ & $\begin{array}{l}\text { (Cooper, 2009); (MacGregor et al., 2010); (Ahonen \& Hämäläinen, 2012); (Yang \& Holgaard, 2012); } \\
\text { (Schoonmaker \& Carayannis, 2013); (Kimatu, 2015); (Nordberg, 2015); (Parveen et al., 2015); (Koleh- } \\
\text { mainen et al., 2016); (Ponchek, 2016); (Aryati, 2017); (Van Horne \& Dutot, 2017); (Iqbal et al., 2018); } \\
\text { (Malva et al., 2018) }\end{array}$ \\
\hline
\end{tabular}

\section{Conclusions}

This paper has reviewed the literature on helix relationships and their role in them by civil society. The research has been carried out in two phases. First, a bibliometric analysis of papers analyzing the role of civil society in innovation systems was carried out, and second, a content analysis of the concept and definition of civil society was performed.

Current regional innovation systems suggest the incorporation of a fourth pillar (fourth helix) representing the actions and opinions of citizens (Carayannis et al., 2018). In this innovation model, the Triple Helix paradigm is extended by assuming that society is a key actor in innovation processes, academia, industry, and government (Carayannis \& Grigoroudis, 2016). The literature uses the label "users," "citizens," or "civil society" (Kolehmainen et al., 2016). From the bibliometric analysis conducted, the following conclusions can be highlighted:

The quadruple and quintuple helix is an area of study of growing interest for researchers, managers, and decision-makers. There has been an increase in publications in recent years. A total of 258 authors are working on this topic, but only $7 \%$ of them have collaborated on more than one article. The most prominent authors are Etzkowitz, Carayannis, and Campbell.
The publications are grouped into 5 clusters, as a result of the co-occurrence analysis, and highlight the following topics: i) triple, quadruple, and quintuple helix models, ii) innovation, iii) ecosystems for entrepreneurship and technology transfer, iv) intelligent regions and v) civil society. In addition, the strategic map identifies three themes as basic topics in the study; the first is a helix whose works address triple helix models. The second theme is a quadruple helix, which incorporates research on innovation systems, collaboration, technology transfer, and the concept of society. The last theme is innovation, whose papers address Smart Cities, open innovation, research, universities, and the outcome of the triple helix. As themes under development, there are three topics. The first one is the quintuple helix, which incorporates the role of democracy in the processes. The second is knowledge, which investigates innovation networks, clusters, and knowledge management. And the last theme is the theory, which includes theoretical aspects that address the quadruple and quintuple helix models. The results are interesting for academics. They show the countries that are more likely to develop collaborative work. They could work together, highlighting the Netherlands and the United States with a large volume of cooperative research. Authors from other countries such as Italy, Spain, Sweden, China, Lithuania, and Romania visualize actions that can be taken to initiate collaborative work with other countries. 
Finally, from the content analysis, the results show the great diversity of concepts and definitions existing in the literature on what is understood by the concept of civil society. From this analysis, different perspectives of the concept of civil society can be appreciated: from the demand side, from the media and culture, from independent nonprofit organizations, and from intermediate organizations.

\section{Acknowledgments}

This article has been prepared within the framework of the Ibero-American Network of Universities for Innovation and Sustainable Development (REDUiS), a Thematic Network financed by the Ibero-American Science and Technology for Development Program (CYTED).

\section{Referencias}

Afonso, O., Monteiro, S., \& Thompson, M. (2012). A growth model for the quadruple helix. Journal of Business Economics and Management, 13(5), 849-865. https://doi.org/10.3846/16111699.2011.626438

Agostini, L., \& Nosella, A. (2018). Inter-organizational relationships involving SMEs: A bibliographic investigation into the state of the art. Long Range Planning, 52(1), 1-31. https://doi.org/https://doi. org/10.1016/j.lrp.2017.12.003

Ahonen, L., \& Hämäläinen, T. (2012). Sustaining Innovation: Collaboration Models for a Complex World. Sustaining Innovation: Collaboration Models for a Complex World, 1-170. https://doi. org/10.1007/978-1-4614-2077-4

Ardito, L., Ferraris, A., Petruzzelli, A. M., Bresciani, S., \& Del Giudice, M. (2019). The role of universities in the knowledge management of smart city projects. Technological Forecasting and Social Change, 142, 312-321.

Aria, M., \& Cuccurullo, C. (2017). bibliometrix: An R-tool for comprehensive science mapping analysis. Journal of Informetrics, 11(4), 959-975. https://doi.org/10.1016/j.joi.2017.08.007

Arnkil, R., Järvensivu, A., Koski, P., \& Piirainen, T. (2010). Exploring Quadruple Helix. Outlining user-oriented innovation models $(85 / 2010)$.

Aryati, A. (2017). 기사 (Article) 와 안내문 (Information) [. The Eletronic Library, 34(1), 1-5.

Björk, P. (2014). The DNA of Tourism Service Innovation: A Quadruple Helix Approach. Journal of the Knowledge Economy, 5(1), 181202. https://doi.org/10.1007/s13132-014-0183-x

Carayannis, E. G., Barth, T. D., \& Campbell, D. F. J. (2012). The Quintuple Helix innovation model: global warming as a challenge and driver for innovation. Journal of Innovation and Entrepreneurship, 1(2), 72-73.

Carayannis, E. G., \& Campbell, D. F. J. (2009). "Mode 3" and "Quadruple Helix": Toward a 21st century fractal innovation ecosystem. International Journal of Technology Management, 46(3-4), 201-234. https://doi.org/10.1504/ijtm.2009.023374
Carayannis, E. G., \& Campbell, D. F. J. (2011). Open Innovation Diplomacy and a 21st Century Fractal Research, Education and Innovation (FREIE) Ecosystem: Building on the Quadruple and Quintuple Helix Innovation Concepts and the "Mode 3" Knowledge Production System. Journal of the Knowledge Economy, 2(3), 327-372. https://doi. org/10.1007/s13132-011-0058-3

Carayannis, E. G., \& Campbell, D. F. J. (2018). Quadruple and quintuple helix innovation systems and mode 3 knowledge production. Handbook of Cyber-Development, Cyber-Democracy, and Cyber-Defense, 9-27. https://doi.org/10.1007/978-3-319-09069-6_56

Carayannis, E. G., Grigoroudis, E., Campbell, D. F. J., Meissner, D., \& Stamati, D. (2018). The ecosystem as helix: an exploratory theorybuilding study of regional co-opetitive entrepreneurial ecosystems as Quadruple/Quintuple Helix Innovation Models. $R$ and $D$ Management, 48(1), 148-162. https://doi.org/10.1111/radm.12300

Carayannis, E. G., Grigoroudis, E., Stamati, D., \& Valvi, T. (2019). Social Business Model Innovation: A Quadruple\&\#x002F;Quintuple Helix-Based Social Innovation Ecosystem. IEEE Transactions on Engineering Management, PP, 1-14. https://doi.org/10.1109/ TEM.2019.2914408

Carayannis, E. G., \& Rakhmatullin, R. (2014). The Quadruple / Quintuple Innovation Helixes and Smart Specialisation Strategies for Sustainable and Inclusive Growth in Europe and Beyond. Journal of Knowledge Economics, 5, 212-239. https://doi.org/10.1007/s13132014-0185-8

Carayannis, E., \& Grigoroudis, E. (2016). Quadruple innovation Helix and smart specialization: Knowledge production and national competitiveness. Foresight and STI Governance, 10(1), 31-42. https:// doi.org/10.17323/1995-459x.2016.1.31.42

Casaramona, A., Sapia, A., \& Soraci, A. (2015). How TOI and the Quadruple and Quintuple Helix Innovation System Can Support the Development of a New Model of International Cooperation. Journal of the Knowledge Economy, 6(3), 505-521. https://doi.org/10.1007/ s13132-015-0253-8

Charalabidis, Y., Alexopoulos, C., Vogiatzis, N., \& Kolokotronis, D. E. (2019). A 360-degree model for prioritizing smart cities initiatives, with the participation of municipality officials, citizens and experts. In Public Administration and Information Technology (Vol. 34). https://doi.org/10.1007/978-3-319-89474-4_7

Cooper, D. (2009). University-civil society (u-cs) research relationships: The importance of a 'fourth helix' alongside the 'triple helix' of university-industry-government (u-i-g) relations. South African Review of Sociology, 40(2), 153-180. https://doi.org/10.1080/215285 86.2009.10425106

Cunningham, J. A., \& O’Reilly, P. (2018). Macro, meso and micro perspectives of technology transfer. The Journal of Technology Transfer, 43(3), 545-557. 
Dameri, R. P., Negre, E., \& Rosenthal-Sabroux, C. (2016). Triple helix in smart cities: A literature review about the vision of public bodies, universities, and private companies. Proceedings of the Annual Hawaii International Conference on System Sciences, 2016-March, 2974-2982. https://doi.org/10.1109/HICSS.2016.372

Del Vecchio, P., Elia, G., Ndou, V., Secundo, G., \& Specchia, F. (2017). Living lab as an approach to activate dynamic innovation ecosystems and networks: An empirical study. International Journal of Innovation and Technology Management, 14(5), 1-18. https://doi.org/10.1142/ S0219877017500249

Dhewanto, W., Herliana, S., Yunita, F., Nur Rizqi, V., \& Williamson, I. O. (2020). Quadruple Helix Approach to Achieve International Product Quality for Indonesian Food SMEs. Journal of the Knowledge Economy. https://doi.org/10.1007/s13132-020-00644-2

Distefano, F., Gambillara, G., \& Di Minin, A. (2016). Extending the Innovation Paradigm: a Double 'I' Environment and Some Evidence from BRIC Countries. Journal of the Knowledge Economy, 7(1), 126154. https://doi.org/10.1007/s13132-015-0299-7

Etzkowitz, H., \& Viale, R. (2010). Polyvalent knowledge and the entrepreneurial university: A third academic revolution? Critical Sociology, 36(4), 595-609. https://doi.org/10.1177/0896920510365921

Galvão, A., Mascarenhas, C., Gouveia Rodrigues, R., Marques, C. S., \& Leal, C. T. (2017). A quadruple helix model of entrepreneurship, innovation and stages of economic development. Review of International Business and Strategy, 27(2), 261-282. https://doi.org/10.1108/ RIBS-01-2017-0003

Galvao, A., Mascarenhas, C., Marques, C., Ferreira, J., \& Ratten, V. (2019). Triple helix and its evolution: a systematic literature review. Journal of Science and Technology Policy Management, 10(3), 812833. https://doi.org/10.1108/JSTPM-10-2018-0103

García-Terán, J., \& Skoglund, A. (2019). A Processual Approach for the Quadruple Helix Model: the Case of a Regional Project in Uppsala. Journal of the Knowledge Economy, 10(3), 1272-1296. https://doi. org/10.1007/s13132-018-0521-5

Gedminaitė-Raudonė, Ž., Vidickienė, D., \& Vilkè, R. (2019). Unused potential for smart specialization development through collaboration: Lithuanian case. Agricultural Economics (Czech Republic), 65(10), 463-469. https://doi.org/10.17221/98/2019-AGRICECON

Geldes, C., \& Heredia, J. (2016). Cooperación: un tema pendiente para la innovación empresarial. Gestión y Tendencias, 1 (6), 6-9.

Grimaldi, D., \& Fernandez, V. (2017). The alignment of University curricula with the building of a Smart City: A case study from Barcelona. Technological Forecasting and Social Change, 123, 298-306.
Grundel, I., \& Dahlström, M. (2016). A Quadruple and Quintuple Helix Approach to Regional Innovation Systems in the Transformation to a Forestry-Based Bioeconomy. Journal of the Knowledge Economy, 7(4), 963-983. https://doi.org/10.1007/s13132-0160411-7

Hasche, N., Höglund, L., \& Linton, G. (2020). Quadruple helix as a network of relationships: creating value within a Swedish regional innovation system. Journal of Small Business and Entrepreneurship, 32(6), 523-544. https://doi.org/10.1080/08276331.2019.1643134

Iqbal, J., Kousar, S., \& ul Hameed, W. (2018). Antecedents of sustainable social entrepreneurship initiatives in Pakistan and Outcomes: Collaboration between quadruple helix sectors. Sustainability (Switzerland), 10(12). https://doi.org/10.3390/su10124539

Ivanova, I. (2019). The synergy and cycle values in regional innovation systems: The case of Norway. Форсайm, 13(1 (eng)).

Johnson, W. H. A. (2008). Roles, resources and benefits of intermediate organizations supporting triple helix collaborative R\&D: The case of Precarn. Technovation, 28(8), 495-505. https://doi.org/10.1016/j. technovation.2008.02.007

Kang, Y., \& Jiang, J. (2020). Revisiting the innovation systems of cross-border cities: the role of higher education institution and crossboundary cooperation in Hong Kong and Shenzhen. Journal of Higher Education Policy and Management, 42(2), 213-229. https://doi.or g/10.1080/1360080X.2019.1701849

Kimatu, J. N. (2015). Evolution of strategic interactions from the triple to quad helix innovation models for sustainable development in the era of globalization. Journal of Innovation and Entrepreneurship, 5(1), 0-6. https://doi.org/10.1186/s13731-016-0044-x

Klenk, N. L., \& Hickey, G. M. (2013). How can formal research networks produce more socially robust forest science? Forest Policy and Economics, 37, 44-56. https://doi.org/10.1016/j.forpol.2012.05.006

Kolehmainen, J., Irvine, J., Stewart, L., Karacsonyi, Z., Szabó, T., Alarinta, J., \& Norberg, A. (2016). Quadruple Helix, Innovation and the Knowledge-Based Development: Lessons from Remote, Rural and Less-Favoured Regions. Journal of the Knowledge Economy, 7(1), 23-42. https://doi.org/10.1007/s13132-015-0289-9

Leydesdorff, L. (2012). The Triple Helix , Quadruple Helix , ... , and an $\mathrm{N}$-Tuple of Helices : Explanatory Models for Analyzing the Knowledge-Based Economy? Journal of Knowledge Economics, 3, 25 35. https://doi.org/10.1007/s13132-011-0049-4

Lindberg, M., Danilda, I., \& Torstensson, B. M. (2012). Women Resource Centres-A Creative Knowledge Environment of Quadruple Helix. Journal of the Knowledge Economy, 3(1), 36-52. https://doi. org/10.1007/s13132-011-0053-8 
Lindberg, M., Lindgren, M., \& Packendorff, J. (2014). Quadruple Helix as a Way to Bridge the Gender Gap in Entrepreneurship: The Case of an Innovation System Project in the Baltic Sea Region. Journal of the Knowledge Economy, 5(1), 94-113. https://doi.org/10.1007/ s13132-012-0098-3

Loi, M., Castriotta, M., \& Di Guardo, M. C. (2016). The theoretical foundations of entrepreneurship education: How co-citations are shaping the field. International Small Business Journal, 34(7), 948-971. https://doi.org/10.1177/0266242615602322

MacGregor, S. P., Marques-Gou, P., \& Simon-Villar, A. (2010). Gauging Readiness for the Quadruple Helix: A Study of 16 European Organizations. Journal of the Knowledge Economy, 1(3), 173-190. https://doi.org/10.1007/s13132-010-0012-9

Mahr, T. (2017). Developing Touristic Destination - Innovation Performance Issues. Interdisciplinary Description of Complex Systems, 15(1), 49-65. https://doi.org/10.7906/indecs.15.1.4

Malik, A., Sharma, P., Pereira, V., \& Temouri, Y. (2021). From regional innovation systems to global innovation hubs: Evidence of a Quadruple Helix from an emerging economy. Journal of Business Research, $128,587-598$.

Malva, J. O., Amado, A., Rodrigues, A., Mota-Pinto, A., Cardoso, A. F., Teixeira, A. M., Todo-Bom, A., Devesa, A., Ambrósio, A. F., Cunha, A. L., Gomes, B., Dantas, C., Abreu, C., Santana, I., Bousquet, J., Apóstolo, J., Santos, L., de Almeida, L. M., Illario, M., ... Veríssimo, M. T. (2018). The quadruple helix-based innovation model of reference sites for active and healthy ageing in Europe: The Ageing@ Coimbra case study. Frontiers in Medicine, 5(MAY). https://doi. org/10.3389/fmed.2018.00132

Martínez, M. A., Cobo, M. J., Herrera, M., \& Herrera-Viedma, E. (2014). Analyzing the Scientific Evolution of Social Work Using Science Mapping. Research on Social Work Practice, 25(2), 257-277. https://doi.org/10.1177/1049731514522101

Mavroeidis, V., \& Tarnawska, K. (2017). Toward a New Innovation Management Standard. Incorporation of the Knowledge Triangle Concept and Quadruple Innovation Helix Model into Innovation Management Standard. Journal of Knowledge Economics, 8, 653-671. https://doi.org/10.1007/s13132-016-0414-4

McAdam, M., Miller, K., \& McAdam, R. (2016). Situated regional university incubation: A multi-level stakeholder perspective. Technovation, 50-51(October), 69-78. https://doi.org/10.1016/j.technovation.2015.09.002

Miller, K., Mcadam, R., Moffett, S., Alexander, A., \& Puthusserry, P. (2016). Knowledge transfer in university quadruple helix ecosystems: An absorptive capacity perspective. $R$ and $D$ Management, 46(2), 383-399. https://doi.org/10.1111/radm.12182
Mora, L., Deakin, M., \& Reid, A. (2019). Strategic principles for smart city development: A multiple case study analysis of European best practices. Technological Forecasting and Social Change, 142(December 2017), 70-97. https://doi.org/10.1016/j.techfore.2018.07.035

Mulet-Forteza, C., Genovart-Balaguer, J., Mauleon-Mendez, E., \& Merigó, J. M. (2018). A bibliometric research in the tourism, leisure and hospitality fields. Journal of Business Research, November, 1-9. https://doi.org/10.1016/j.jbusres.2018.12.002

Nordberg, K. (2015). Enabling regional growth in peripheral nonuniversity regions-The impact of a quadruple helix intermediate organisation. Journal of the Knowledge Economy, 6(2), 334-356. https:// doi.org/10.1007/s13132-015-0241-z

Paniccia, P., \& Baiocco, S. (2018). Co-evolution of the university technology transfer: Towards a sustainability-oriented industry: Evidence from Italy. Sustainability, 10(12), 4675.

Parente, R., Feola, R., Cucino, V., \& Catolino, G. (2015). Visibility and Reputation of New Entrepreneurial Projects from Academia: the Role of Start-Up Competitions. Journal of the Knowledge Economy, 6(3), 551-567. https://doi.org/10.1007/s13132-015-0255-6

Parveen, S., Senin, A. A., \& Umar, A. (2015). Organization culture and open innovation: A quadruple helix open innovation model approach. International Journal of Economics and Financial Issues, 5(2), 335-342.

Ponchek, T. (2016). To Collaborate or Not to Collaborate? A Study of the Value of Innovation from a Sectoral Perspective. In Journal of the Knowledge Economy (Vol. 7, Issue 1). Journal of the Knowledge Economy. https://doi.org/10.1007/s13132-015-0290-3

Porto-Gomez, I., Zabala-Iturriagagoitia, J. M., \& Leydesdorff, L. (2019). Innovation systems in México: A matter of missing synergies. Technological Forecasting and Social Change, 148(August), 119721. https://doi.org/10.1016/j.techfore.2019.119721

Ranga, M. (2018). Smart specialization as a strategy to develop earlystage regional innovation systems. European Planning Studies, 26(11), $2125-2146$.

Roman, M., Varga, H., Cvijanovic, V., \& Reid, A. (2020). Quadruple Helix Models for Sustainable Regional Innovation: Engaging and $\mathrm{Fa}-$ cilitating Civil Society Participation. Economies, 8(48), 1-15.

Salter, B., \& Salter, C. (2010). Governing innovation in the biomedicine knowledge economy: Stem cell science in the USA. Science and Public Policy, 37(2), 87-100. https://doi.org/10.3152/030234210X489617

Schoonmaker, M. G., \& Carayannis, E. G. (2013). Mode 3: A Proposed Classification Scheme for the Knowledge Economy and Society. Journal of the Knowledge Economy, 4(4), 556-577. https://doi. org/10.1007/s13132-012-0097-4 
Schütz, F., Heidingsfelder, M. L., \& Schraudner, M. (2019). Co-shaping the Future in Quadruple Helix Innovation Systems: Uncovering Public Preferences toward Participatory Research and Innovation. She Ji, 5(2), 128-146. https://doi.org/10.1016/j.sheji.2019.04.002

Snyder, H. (2019). Literature review as a research methodology: An overview and guidelines. Journal of Business Research, 104(March), 333-339. https://doi.org/10.1016/j.jbusres.2019.07.039

Terstriep, J., Rehfeld, D., \& Kleverbeck, M. (2020). Favourable social innovation ecosystem(s)?-An explorative approach. European Planning Studies, 28(5), 881-905. https://doi.org/10.1080/09654313.2019 .1708868

Vallaster, C., Kraus, S., Merigó Lindahl, J. M., \& Nielsen, A. (2019). Ethics and entrepreneurship: A bibliometric study and literature review. Journal of Business Research, 99(February), 226-237. https://doi. org/10.1016/j.jbusres.2019.02.050

Van Horne, C., \& Dutot, V. (2017). Challenges in technology transfer: an actor perspective in a quadruple helix environment. Journal of Technology Transfer, 42(2), 285-301. https://doi.org/10.1007/s10961016-9503-6

van Waart, P., Mulder, I., \& de Bont, C. (2016). A Participatory Approach for Envisioning a Smart City. Social Science Computer Review, 34(6), 708-723. https://doi.org/10.1177/0894439315611099
Vilkè, R., Gedminaitè-Raudonè, Ž., \& Vidickienė, D. (2020). Collaboration for the socially responsible development of rural regions: biogas production in Lithuanian farms. Social Responsibility Journal, 16(6), 877-898. https://doi.org/10.1108/SRJ-07-2019-0235

Waltman, L., \& Van Eck, N. J. (2012). A new methodology for constructing a publication-level classification system of science. Journal of the American Society for Information Science and Technology, 63(12), 2378-2392.

Yang, Y., \& Holgaard, J. E. (2012). The important role of civil society groups in eco-innovation: a triple helix perspective. Journal of Knowledge-Based Innovation in China, 4(2), 132-148. https://doi. org/10.1108/17561411211235730

Yoon, J., Yang, J. S. W., \& Park, H. W. (2017). Quintuple helix structure of Sino-Korean research collaboration in science. Scientometrics, 113(1), 61-81. https://doi.org/10.1007/s11192-017-2476-x

Yun, J. J., \& Liu, Z. (2019). Micro-and macro-dynamics of open innovation with a quadruple-helix model. In Sustainability (Vol. 11, Issue 12, p. 3301). Multidisciplinary Digital Publishing Institute. 